Editorial

\title{
Geospatial Modeling of River Systems
}

\author{
Karl-Erich Lindenschmidt * (iD) and Meghan Kathleen Carr \\ Global Institute for Water Security, 11 Innovation Blvd., Saskatoon, Saskatchewan, SK S7N 3H5, Canada; \\ meghan.carr@usask.ca \\ * Correspondence: karl-erich.lindenschmidt@usask.ca; Tel.: +1-306-966-6174
}

Received: 1 February 2018; Accepted: 4 March 2018; Published: 7 March 2018

\begin{abstract}
Within the context of fluvial systems, geospatial modeling of river networks consists of describing certain patterns in the geographical or geomorphological "fabric" along the course of rivers or streams and correlating these patterns to physical, ecological, biological and chemical processes in the river/stream system's aquatic environment. Patterns may consist of different sets of similar sequences of geomorphological characteristics, sediment substrate type or flow velocity fields. These patterns will influence processes by defining, for example, behaviors in river ice formation or breakup (physical), fish habitat types (ecological) and transformations in water-quality constituents (biological and chemical). In this special issue of Geospatial Modeling of River Systems, we invited papers to present models and data that correlate geographic/geomorphic features of a river or stream system with physical/ecological/biological/chemical processes in the lotic aquatic environment.
\end{abstract}

Keywords: aquatic ecosystems; fluvial systems; geospatial modeling

\section{Introduction}

\subsection{Geomorphological Processes}

Fluvial geomorphology examines river channel morphology resulting from the interaction of fluid flow and erodible channel boundary materials [1,2]. Such interactions are highly spatially and temporally variable and involve the processes of sediment entrainment, transport, and deposition which occur as the channel boundary maintains coherent structure by withstanding and adjusting to a wide range of forces. Boundary materials may be non-cohesive and readily erodible, or cohesive and highly resistant to erosion. Bedrock channels or those with high silt or clay content are much more cohesive than sand and gravel and therefore adjust more slowly. Flow quantity and timing is intrinsic to the ecological integrity of river systems as these parameters are correlated with many critical physicochemical river characteristics such as channel geomorphology, water temperature, water quality, and habitat diversity [3,4]. Climate is a primary control influencing river hydrology and geomorphology as it impacts the precipitation timing and quantity which establishes the hydrologic character of a drainage basin $[5,6]$, as well as the presence of vegetation, which stabilizes channel banks and hillslopes [6]. Geomorphological features of rivers such as bed form, sediment transport, and the relative position of bed and banks, can be altered by changes in flow regime that influence processes of erosion and deposition [7]. The rate of sediment transport is greatest during dominant or effective discharge, approximately bankfull flood [8].

River flood events can occur when bankfull discharge is surpassed due to snowmelt, drainage, extreme weather events, obstructions, etc. Both drainage basin and channel factors contribute major geomorphic response to flooding and can greatly alter the physical structure of rivers [6]. Geomorphic response dictates modifications to the floodplain, channel pattern and channel geometry. Floodplain modifications include scour, fine-grained sediment deposition, coarse overbank gravels and debris 
flow levees [9]. Channel widening, scour, and inchannel deposition modify channel geometry, while channel pattern changes such as meander cutoffs, braiding, and chutes may occur [9].

From a geomorphological perspective, Schumm [6] organizes river variability and complexity into four main categories: upstream controls, fixed local controls, variable local controls and downstream controls related to gradient change. Upstream controls include tectonics, which influences landscape relief and is an important factor in determining river type, lithology, or physical geological characteristics of the catchment; and climate, which is a controlling factor of hydrology [6]. Fixed local controls include bedrock, tributaries, active tectonics, and valley morphology. Bedrock can influence river width and meander migrations, while tributaries can potentially introduce large amounts of sediments and flow, substantially impacting channel morphology and ecology $[1,6]$. Active tectonics can cause local changes in stream gradient which result in stream aggradation or degradation, while channel shape, sinuosity and bed material characteristics may also shift. Variable local controls include floods, vegetation, and accidents (log jams, ice processes, earthquakes, etc.). Anthropogenic influences can also play a large part in river variability and complexity and, depending on the sensitivity of a given river, can incite changes ranging from negligible to drastic [6].

\subsection{Geomorphology and Ecology}

Geomorphology has often been recognized as an important factor in defining biological $[10,11]$ and ecological characteristics of rivers $[12,13]$ and ultimately the shaping of aquatic habitat $[13,14]$. The term habitat refers to a location or environment where an organism is most likely to be found and can include physical, chemical and biological characteristics that allow the organism to achieve various life history requirements, such as spawning, feeding, and overwintering. Here, we consider habitats in terms of physical characteristics as they relate to geomorphological features and processes. Retention of particulate organic matter (POM) and course particulate organic matter (CPOM) are influenced by geomorphic features [8]. In large rivers, flood plains are often the primary location of POM deposition and storage, while studies in smaller order rivers have found that meandering reaches [15] and pool features [16] retain larger quantities of CPOM in comparison to straightened sections or areas with greater velocities and shallower depths. The ecological significance of geomorphic features is reflected in their associations with habitats of different flora and fauna [17]. Pools, riffles, and runs have been found to support different algae and macrophytes [18], macroinvertebrate assemblages [19-21] and distinct fish habitats [22].

As an example, geomorphic condition significantly influences fish community diversity and productivity and is of primary importance for river rehabilitation efforts [23,24]. Riverine fish exhibit complex life cycles and habitat use patterns associated with variations in body size as they grow from embryo to adult [25]. Geomorphological processes are directly and indirectly linked to the formation and maintenance of different habitat areas used during these stages of development. Physical habitat conditions can directly impact distribution of species as well as act indirectly by determining type and abundance of food resources [26] and influence the roles of competition or predation [27]. Often, species have different habitat requirements for foraging or summering, spawning, rearing, and overwintering. For example, consider the foraging and spawning habitats of a variety of species: Lake Sturgeon (Acipenser fulvescens), Common Carp (Cyprinus carpio), Sauger (Sander Canadensis), and Carmine Shiner (Notropis percobromus). These species cover a range of sizes, lifespans, and guilds, reflecting the diversity of Prairie fishes.

Foraging habitat is essentially defined by the presence of food items. In this sense, foraging habitat for fish can be considered the habitat of food items themselves as well as the areas where feeding mechanisms the fish possess are most successful. Substrate is closely correlated with many fluvial process variables, such as water level, flow velocity, etc., and is considered the primary condition for the survival of benthic animals [8]. Lake Sturgeon feed over fine substrates of sand, mud and gravel, suggesting areas of lower velocities that allow deposition of such substrates. Similarly, Common Carp prefer slower-moving waters in streams, ponds, rivers and lakes, and are typically benthic 
feeders, preferring shallow water and soft substrates for feeding [28]. Upstream sediment and particulate organic matter sources must also be maintained in order to replenish these soft substrates. Silty substrates are generally nutrient-rich with greater amounts of fine particulate organic matter; thus, collector-gatherers predominate in soft substrates with densities and biomass increasing with increasing total phosphorous, while collector-filterers and scrapers are more dominant in gravel substrates [8]. The migratory nature of Lake Sturgeon allows them to take advantage of an array of foraging areas that have relatively low velocities and a range of substrates supporting different macroinvertebrate assemblages and large invertebrates such as crayfish. Carmine Shiner are typically found near riffles in creeks and small rivers over clean gravel or rubble substrates during summering and spawning [29]. Their diet is mainly comprised of aquatic and terrestrial insects, although vegetation, diatoms, and filamentous algae are also consumed [30,31]. Carmine Shiner feed based mainly on sight, relying on flows to bring food items past them, either within the water column or at the surface, so that they can locate them by sight and catch them with their terminal mouths. This species is also very sensitive to turbidity, and although the exact effects are not known, it possibly interferes with visual feeding [32]. More stable substrates, such as gravel and cobble, also allow the production of biofilms and filamentous algae [8]. Sauger are most often associated with rocky substrates, though they have been found on substrates ranging from clay and silt to rubble and boulders [28]. This species feeds on a variety of invertebrates and small fishes, depending on the size of the Sauger and season.

For spawning, Carmine Shiners and Lake Sturgeon are both often associated with swift currents and larger-sized substrates. Lake Sturgeon spawn in larger rivers at riffles or beneath rapids over heterogeneous substrates with high proportions of gravel [33]. Though little information exists on the spawning habits of Carmine Shiner in Canada, they are likely similar to those of the Rosyface Shiner (Notropis rubellus) [28]. The Rosyface Shiner has been observed spawning in riffles over depressions in clean gravel [30], which are often nests constructed by other cyprinids [34]. The eggs hatch after 2.5 days, and larvae remain in the bottom gravel, presumably until the yolk is absorbed [30]. It has been suggested that larger-sized substrates such as gravel and cobble provide interstitial spaces that protect eggs from predation and relatively high velocities reduce sedimentation, which can cause suffocation [35]. Similarly, Sauger spawn over gravel to rubble or rocky substrates, but in deeper water, rather than riffles $[28,36]$. These spawning habitats are dependent upon lithology, which can dictate which substrates are present, as well as substantial flows and effective stream gradient to prevent deposition of fine sediments or exposure to desiccation. Mature Common Carp move to vegetated shorelines or flooded areas to spawn, their adhesive eggs attaching to submerged vegetation and hatching after 4 days [28]. Like Lake Sturgeon, adult Common Carp often have to make considerable spawning migrations to find suitable backwaters and flooded vegetation.

Other physical habitat variables have been linked to geomorphic characteristics of rivers. Baxter and Hauer's [37] multiscale study identified three different scales of habitat associations for Bull Trout (Salvelinus confluentus) redds (nests) in tributaries of a Montana river. At a 5-10 km scale, redds were associated with low-gradient bounded alluvial valley segments (BAVS). Groundwater upwellings within BAVS created thermal refugia for incubating eggs, preventing freezing during winter months; and at an even finer scale, sites with localized downwelling were chosen as being likely to ensure adequate oxygenation of the eggs. The large-scale geomorphological context of these habitats acted as a filter for smaller, local scale patterns in redd sites [38].

\subsection{Channel Planform and Physical Habitats}

The majority of existing studies investigate relationships between habitat and geomorphology in relatively small, often wadeable, streams (order 1-5), where monitoring protocols tend to be well established and geomorphological variables can be measured with relative ease $[11,13]$. Such thorough data collection becomes less attainable in larger rivers, where greater depths, widths, discharge and flow velocities impede both active and passive data collection methods. The increase in study area also increases the time and effort required to collect data which is often at odds with financial and 
temporal constraints of a given study or monitoring program. There are also boundless hydraulic and geomorphic variables that can be measured in an effort to describe the fluvial geomorphic character of rivers. These parameters vary in spatial and temporal scales and some are more readily measured than others. For example, flow velocity is an instantaneous variable often used to describe aquatic habitats [39]. Although velocity ranges are valuable descriptors of known habitat areas, identification of possible habitat areas using such a parameter is not feasible because local velocities are constantly in flux, and most sampling and monitoring methodologies reduce this highly variable parameter to an average value that does not accurately reflect the heterogeneity present in a given cross-section or reach. Two streams or river reaches may have similar mean velocities, yet exhibit disparate velocity profiles $[40,41]$. A larger-scale understanding of the relative differences in flow velocities within or between reaches is likely to be more informative for the characterization of habitat patches in large river systems. Many of these possible hydro-geomorphological variables are correlated and often their influence is reflected in measures of higher order variables. The most readily acquired geomorphological data for large rivers are variables describing the planform channel morphology. Planform variables describe the configuration of the river channel and include measurements such as channel width, meander length, sinuosity, fractal dimension, and radius of curvature. Although relationships between the spatial distribution of different species, assemblages, or communities and various abiotic and biotic factors are often complex, planform channel variables representative of geomorphic character can act as higher order proxies for myriad possible predictors. Identifying patterns in channel planform can provide insight into the physical features present in different reaches and allow us to infer which are likely to coincide with different habitats.

Different planform shapes and types are influenced by discharge, sediment caliber and availability, and the dominant type of sediment transport occurring in a given reach. Channel size is influenced by discharge, though how a river responds to changes in discharge depends upon the hydrologic regime [42] and bank material. Rivers with flashier regimes tend to increase in width much more rapidly than those with smaller peak flows, and channels with less cohesive bank materials like sand tend to be more susceptible to the influence of discharge variability [1,43]. Channel planform is related to habitat hydraulics and has been found to influence the distribution of cross-stream and vertical velocities, with more sinuous reaches exhibiting more complex flow habitats as measured by three-dimensional geometry and motion of flow [41]. Channel slope and sinuosity have been correlated with fish species composition and diversity [24,44]. In a comparison of a channelized vs. a meandering section of an agricultural stream, Frothingham et al. [45] found that the meandering reach had greater spatial variability in channel morphology and, by extension, physical habitat than the channelized reach. Sampling of the fish communities within the two contrasting reaches determined that species richness was similar between the two reaches but the meandering reach had greater average biomass and $25 \%$ greater abundance than the channelized reach [45]. Channelized reaches have also been associated with less variable bed elevations, further supporting the notion of reduced habitat complexity [41]. Sinuosity has also been linked to increased large/course woody debris [46,47]. Nakamura and Swanson [47] found that channel width and sinuosity were the main factors controlling woody debris production and storage, with lateral cutting and landslides facilitating introduction of woody debris in sinuous reaches of Lookout Creek, Oregon.

Slope adjusts more slowly than other channel variables, such as channel width and depth, velocity, degree of sinuosity and grain size of sediment load [8]. Changes in slope result from changes in watershed conditions that disrupt sediment transport continuity, bed load starvation leading to degradation and excessive bed-load inputs leading to aggradation [1]. In general, an increase in channel gradient leads to an increase in velocity and can serve as a proxy for instream-velocity measurements when identifying large-scale patterns in environmental characteristics, which may influence habitat suitability. Fractal dimension, a measure of the irregularity or intricacy in trains of meanders and relating to changes in overall river course, is another planform variable that has been linked to large-scale geomorphic character [48-50]. Fractal dimension has been found to reflect 
changes in tectonic provinces of varying uplifting intensity and age [51]. Beauvais et al. [52] proposed that patterns in channel planform fractal dimension, which they termed the textural fractal dimension, to be related to the influence of local environmental factors such as soil type, vegetation cover, runoff and sediment transport. Understanding how planform channel variables relate to instream physical habitat attributes has the potential to inform managers interested in identifying large-scale habitat characteristics in large river systems.

\subsection{River Ecosystem Models and Geospatial Modelling}

Several different riverine ecosystem models have been developed over the past century in an effort to describe structural and functional patterns within and among rivers. Identification of longitudinal biotic zones in streams based on dominant fish species: trout (Salmo), grayling (Thymallus), barbell (Barbus), and bream (Abramis), began in the early twentieth century, but Hynes [53] identified limits in application of such methods due to differences in regional geographic distributions of species and the impacts of activities on species distributions. Since 1980, several models have been developed that have greatly improved our understanding of how dynamic river ecosystems function, and which continue to contribute to current river science research. Five such models are the River Continuum Concept (RCC) [54], the Serial Discontinuity Concept (SDC) [55], the Flood Pulse Concept (FPC) [5], the Riverine Productivity Model (RPM) [56], and the River Wave Concept [57].

The River Continuum Concept (RCC) proposed by Vannote et al. [54] was one of the first ecosystem models to have widespread influence on river science. The RCC views rivers as longitudinal gradients with predictable transitions in physical and biological characteristics from headwaters (orders 1-3), through medium (4-6), to large rivers (>6) [54]. Headwaters rely heavily on allochthonous sources of carbon, mainly leaves from riparian vegetation and collector and gatherer species that can break down such course detritus dominate the macroinvertebrate assemblages [54]. Terrestrial vegetation intercepts most of the sunlight keeping production/respiration $(\mathrm{P} / \mathrm{R})$ ratios $<1$ and helps maintain cool water temperatures, limiting which fish species can inhabit such reaches [54]. Cold-cool water species including trout (Salmonidae), sculpins (Cottidae) and mountain suckers (Catostomus platyrhynchus), are invertivores, feeding primarily on drifting aquatic and terrestrial insects [58]. Medium-sized rivers are wider, deeper, and warmer with terrestrial inputs becoming less important as flow transfers organic matter from upstream and increased sunlight exposure allows autochthanous primary production to occur [54]. $\mathrm{P} / \mathrm{R}$ ratios tend to be $>1$ and grazers and scrapers dominate the macroinvertebrate assemblages. Grazers take advantage of fine particulate organic matter (FPOM) resulting from the processing of coarse particulate organic matter $(\mathrm{CPOM})$ by upstream shredders and scrapers ingest algae growing on surfaces [54]. Coolwater species gradually decline and warm water species begin to dominate the fish assemblage [54]. Biodiversity increases as both invertivores and piscivorous species such as Walleye (Sander vitreus), perch (Perca), and Northern Pike (Esox lucius) thrive [58]. Large rivers are much warmer, wider, and deeper and effects of riparian vegetation become much less significant [54]. Velocities decrease and turbidity and depth attenuate sunlight so $P / R<1$ and FPOM collectors again dominate the macroinvertebrate assemblage with some predaceous species [54]. Some large rivers exhibit semi-lentic characteristics due to decreased velocities and extreme depth and plankton growth increases providing another food source [54]. Warm water species dominate the fish assemblage with catfishes (Ictaluridae), suckers (Catostomidae), and sunfishes (Centrarchidae) adding to the diversity of fish species [58].

Though these generalities provide insight into ecological processes within rivers, there are several shortcomings of the RCC. A prevalent issue is transferability to rivers in different ecozones. This concept was developed based on patterns occurring in pristine temperate zone rivers with forested headwaters. Rivers that originate in unforested regions still support diverse fish assemblages; therefore, other carbon sources must account for such discrepancies. The RCC also fails to address the fact that the majority of rivers in the world today are greatly altered by human use and are faced with extractions, damming, pollution, and adverse land use practices. The RCC is limited in its ability 
to predict fish habitat, as river ecosystems have become extremely fragmented, which disrupts the continuum, altering nutrient and carbon cycling, sediment transport, and the chemical and physical characteristics of habitat both upstream and downstream of barriers. Although some of the overall patterns in fish species and biodiversity may still hold due to temperature limitations, habitat and associated species are much more likely to exhibit patch like distributions rather than transitioning smoothly along a gradient. Further to associations with certain temperature limits, different species may fall into different feeding guilds and often have different habitat requirements depending on season and life stage; thus, habitat associations are much more complex than the longitudinal patterns described by the RCC.

The Serial Discontinuity Concept (SDC) improved upon the RCC by identifying some "exceptions to the rule" $[55,59]$. The SDC recognizes that impoundments can disrupt nutrient spiraling and the continuum of processes described by Vannote et al. [54], and proposed some useful generalizations about the influence of such barriers. For example, because they impede the transport of detritus, headwater dams are likely to have a greater impact on downstream CPOM: FPOM ratios than those in downstream reaches of large rivers [55]. Reducing the influx of CPOM could greatly alter the macroinvertebrate assemblages in these downstream reaches and cause a decline in shredder species [55]. Conversely, headwater impoundments are unlikely to have a substantial effect on downstream $\mathrm{P} / \mathrm{R}$ ratios, but impoundments in large rivers can greatly increase water clarity as flow velocities decrease and transport capacity decreases upon entering the reservoir, allowing sediments and FPOM to settle out of the water column, which can lead to increased P/R ratios downstream $[1,55]$. Changes to the amplitude of seasonal water temperatures, flow regime, nutrient spiraling, and effects of multiple impoundments are also addressed [55]. Though these theoretical perspectives help us understand how impoundments may impact the ecological functioning of river reaches, several limitations and assumptions persist with the SDC and are recognized by the authors. Such assumptions include: inability to account for any disturbances other than impoundment, no pollution present, remaining lotic reaches are not disrupted by reservoir construction, and impoundments are assumed to be thermally stratified deep-release storage reservoirs that do not release either supersaturated nor oxygen deficient waters [55].

The Flood Pulse Concept (FPC) is in fundamental agreement with the RCC principle of a gradient in physical conditions from headwaters to river mouth but argues that it was developed for small temperate streams with permanent lotic habitats [5]. They propose that in floodplain Rivers, flood pulses that connect the main channel to the floodplain are more important in determining the function of floodplain Rivers than position along a river continuum [5]. Floodplain areas provide access to nutrients and organic matter which increases productivity, and also allow access to habitats that are physically distinct from the main channel [5]. They also suggest that river regulation has led to an underestimation of the importance of lateral migration of animals between the main channel and floodplain of large rivers because modified flow regimes have reduced connectivity between the main channel and floodplain. The FPC can offer insight into the distributions of fish species that rely on flood pulses as cues for different life history events such as migration or spawning, or require access to flooded riparian zones to complete such life history requirements. Though Junk et al. [5] place emphasis on floodplain rivers with extreme flood pulses of long duration, such as tropical and subtropical floodplain rivers, reduced access to the floodplain can still negatively impact species in any river with historically predictable seasonal peak flow pulses.

The Riverine Productivity Model (RPM) continues to build upon previous models by addressing the importance of local instream primary production and allochthonous inputs in large rivers [56]. They suggest that previous models underestimate the substantial amounts of organic carbon inputs that can be attributed to local autochthonous production by benthic algae, aquatic vascular plants, mosses and phytoplankton, as well as direct riparian inputs [56]. Such forms of carbon are relatively more labile than benthic organic matter or inputs transported from upstream, suggesting that autochthonous and local terrestrial inputs are more readily assimilated by heterotrophs [56]. Contrary to RCC prediction, 
macroinvertebrate density data from the large rivers in this study suggested that grazers account for a large portion of the total benthic macroinvertebrate assemblage of near-shore habitats. These near-shore areas, in addition to side channels and shallow bars, have reduced flow velocities relative to the main channel, allowing greater retention and processing of local organic matter [56]. It is of note that the RPM was developed based on the analysis of very large deep rivers of southern and Midwestern USA, such as the Mississippi, Ohio and Tennessee Rivers; therefore, results may be biased to these specific river types with restricted channels and firm substrates [56].

Though all of these river ecosystem models provide valuable insight into patterns of ecological functioning within rivers, they are all theoretical frameworks rather than widely applicable tools for identifying which reaches of a river or river network are similar or dissimilar. Geospatial modelling builds on this extensive theoretical foundation by providing a means for delineating large-scale self-emergent patterns and patches within river systems. These patches generally coincide with river reach or river segment scales; the scales at which fish species are actually interacting with the river ecosystem. These patches can also repeat throughout the river and do not follow a gradient like the RCC or result simply due to discontinuities in a gradient as implied by the SDC. Geospatial modelling is much more flexible in its application than the RCC as it does not require a pristine, forested headwater stream in order to identify patterns in geomorphic structure within a river.

\subsection{Response Unit Theory and Development of Geomorphic Response Units (GRU)}

Response units have been used extensively to organize large scale hydrological and geomorphological processes into smaller, computationally manageable units [60-64]. Cammeraat [61] defines response units as: "built of several land units that have a characteristic response with respect to hydrological and geomorphological processes. Each response unit should be identifiable in a proper and preferably easy way ... by selecting key indicators that reflect dominant processes within a response unit".

Response units are commonly used to delineate areas of similar hydrological response within a watershed based on geomorphological (e.g., soil type, geology), topological (e.g., convexity, concavity, slope and aspect) and biological (e.g., vegetation) landscape characteristics paired with temperature and precipitation data to determine response in an output of interest such as runoff $[60,62,65]$. Generally, the majority of response unit characteristics can be derived from readily available Geographic Information System (GIS) data layers with moderate effort. In terms of delineating units of similar response within riverine ecosystems specifically, Thorp at al. [59] have developed Functional Process Zones (FPZ). Their Riverine Ecosystem Synthesis (RES) views rivers as longitudinal arrangements of functionally and structurally similar hydrogeomorphic patches (FPZs) formed by flow and geomorphology characteristics. The theoretical framework associated with FPZs is intensive and lacks a well-defined, readily applicable model for identifying such units.

In contrast, the geomorphic response unit (GRU) method developed by Lindenschmidt and Long [66] is an efficient desktop approach for determining areas of similar geomorphological and hydrological response. Geomorphological patterns and trends operate at inter-annual to decadal temporal scales and are associated with long term biological outputs [66]. A GRU essentially represents the structure of a river segment and provides a link between the hydrological regime and physical habitats to which species respond. The geomorphological parameters sinuosity, fractal dimension, slope and stream width are extracted from stream network and digital elevation model (DEM) GIS layers. Variable values are extracted every $50 \mathrm{~m}$ along the river and principal component analyses (PCA) are preformed to determine orthogonal eigenvalues for each parameter [66]. Eigenvalues are converted to binary values and each unique combination of values across included components yields a different geomorphic Type that can be linked back to each centerline point. Types then represent unique characteristics of the input variables and identify differences and similarities in geomorphological characteristics along the length of the river or network of interest. Patterns in the associations of Types create emergent patterns at a larger scale and allow the delineation of GRUs. 
The 'riverscape' method [67] also correlates geomorphic features to riverine habitat, but include hydraulic information, such as flow velocity, stream power and Froude number, into the geospatial modelling framework. Church and Ferguson [68] emphasize the importance of the movement of water and sediment in characterizing the geomorphological features of rivers. The method is supported by the remote sensing of fluvial systems under study [69]. Other geospatial modelling tools to help with the characterization of fluvial geomorphological characteristics include the River Styles Framework [70], which provides tools to assess the restoration potential and guide remediation strategies [71], and geomorphological mapping [72,73], which allows geomorphological information to be integrated quantitatively into terrain representations. Kondolf and Piégay [74] provide a synthesis of the various tools available to assess fluvial geomorphology for river restoration and management applications.

\section{Contributions}

The papers in this special issue have been grouped into three sections to address different aspects of geospatial modelling of fluvial systems: in-stream geomorphology, river basin morphology and data management for geospatial modelling.

\subsection{In-Stream Geomorphology}

Hosseini et al. [75] and Meissner et al. [76,77] used different modelling approaches to determine the effects of spatial variability and indicators on aquatic ecology. Hosseini et al. [75] applied a deterministic water quality model to determine the impact of location along a river on the sensitivity of ecological parameters (e.g., oxygen demand and growth rate) to water-quality variables (e.g., dissolved oxygen and chlorophyll-a concentrations). The difference in their spatial extents consisted of reaches of the same river, upstream and downstream of a large Prairie reservoir. The flow regulation of the reservoir has a strong impact on lowering the integrity of the downstream reach's aquatic ecosystem, measured on the basis of correlation map, hierarchy index values and water quality indices. A stronger interaction between variables was observed for the more eutrophic upstream reach. These interactions differed between open-water, summer conditions and ice-covered, winter conditions.

Meissner et al. [76,77] developed a geospatial model to easily identify fish and invertebrate habitat along another Prairie river to assist water and wildlife managers to rapidly identify fisheries habitat in need of protection. The study concentrated on fluvial geomorphology (metrics included channel sinuosity, width and slope and fractal dimension) and examining the hydrological and geological processes that shape certain fluvial geomorphological structures and patterns, as developed by Lindenschmidt and Long [66]. Multivariate-derived geomorphic response units (GRU) that categorized reaches along river systems that exhibit similar geomorphic structures were established, thus providing a link between the hydrological regime and species habitat preference. Meissner et al. [76] focused on macro-invertebrate genus groupings as the ecological indicator, whereas the better-performing macroinvertebrate species groups are described in Meissner et al. [77].

\subsection{River Basin Geomorphology}

Similar to the Meissner at al. [76,77] papers, Doll et al. [78] also used macroinvertebrate community metrics, but extended their correlation with in-stream geomorphological features (e.g., bankfull channel cross-sectional area, width-to-depth ratio, channel sinuosity and channel slope) to include morphological features in the river basin (e.g., width of the flood prone area, valley width, valley slope, and substrate). They, too, used principal component analyses to determine correlations between landscape features with macroinvertebrate indices. Qiu et al. [79] modelled groundwater levels with riverine water levels to provide a basis for water quality modelling. Features of the watershed were important in setting up the modelling framework. The same was carried out for a watershed modelling system in Chang et al. [80] in order to study the implications of typhoon-induced sediment transport on riverine ecosystems. 


\subsection{Data Management for Geospatial Modelling}

Important for any modelling exercise is access to sufficient, quality-controlled data. Fuchs et al. [81] present a data management system that tracks substance emissions to help protect freshwater resources. The system, MoRE (Modeling of Regionalized Emissions), also provides modelling capabilities to track pathway-specific emissions and river loads on a catchment scale and scenarios of emission reductions to be simulated. Accurate digital elevation models are also vital to the setup of geospatial models, an example of which is provided by Chowdhury et al. [82] for the lower portion of the Athabasca River basin in Canada.

\section{Conclusions}

\subsection{Synopsis}

Geospatial modelling applications and techniques are diverse and are becoming increasingly common in river sciences research. Spatiotemporal relationships within river systems are complex and highly heterogeneous, with physical, chemical, and ecological processes being connected in three potential spatial dimensions: along longitudinal, lateral, and vertical pathways which act under the fourth dimension, time [83]. Spatial environmental factors constrain where ecological and hydrological phenomena occur within these systems. By viewing such phenomena or events, which are neither random nor uniform, through a geographic filter, geospatial modelling provides a means of describing, explaining and or predicting event occurrence.

In riverine ecology, there has been a shift from viewing rivers simply as sampling points, lines, or gradients to conceptualizing these systems as spatially continuous longitudinal and lateral mosaics [38]. Geospatial modelling tools help define and classify such mosaics which may be defined in a hierarchical fashion, with different spatial scales, major evolutionary events, developmental processes, and time scales of continuous potential persistence [38]. Observations and predictions should be made and tested at the scales at which managers affect change and sampling strategies that include continuous spatial censuses followed by long-term sampling at strategic, rather than randomized, locations may be a more practical approach.

\subsection{Limitations and Future Directions}

Studies addressing spatial hierarchies and links between large-scale geomorphological patterns and fish habitat have occurred in small stream systems, which can be sampled much more efficiently than large rivers. Sampling efficiencies and fish assemblage structure can simultaneously be influenced by the physical, chemical, and biological attributes of aquatic ecosystems [84]. For example, depth can be an important factor influencing both the efficiency of sampling methods as well as fish assemblage structure. Kwak and Peterson [84] suggest using analyses based on qualitative measures such as rank abundance or species presence when sampling conditions are challenging, such as in reservoirs and large rivers. Apparent lack of distinct differences in assemblage between geomorphic features, as determined qualitatively by relative percent abundance, may in fact reflect a limitation of the sampling gear. Habitat characteristics, specific species characteristics and body size, and gear type can all introduce more bias into sampling efforts. Benthic and wide-ranging pelagic species are difficult to sample and species with cryptic coloring and reduced swim bladders are difficult to locate while electrofishing $[84,85]$. Depth and stream width can change capture efficiency, with wider and deeper sections exceeding the catch area (e.g., seine dimensions or electrical field size), allowing fish to avoid the field by either swimming around or sounding [86]. When electrofishing, high velocities can displace stunned fish before they are captured, and refuges created by structures such as vegetation, boulders, and woody debris can limit sampling efficiencies [84,87]. Such biases can result in samples that overrepresent species occupying more easily sampled habitats and underrepresent those in habitats with features that impair sampling [84]. In order to understand whether geomorphological characteristics are related to differences in fish assemblages, future studies must tailor fish sampling 
strategies in efforts to overcome sampling biases that may be prevalent in large rivers. A stratified sampling design whereby a combination of electrofishing and trawl gear types are used at each sample site would provide a more representative sample of assemblage structure encompassing a larger range of body sizes and guilds.

Spatiotemporal relationships within river systems are complex and highly heterogeneous, with riverine habitats and organisms being connected in three potential spatial dimensions: along longitudinal, lateral and vertical pathways which act under the temporal hierarchy of the fourth dimension, time [83]. Spatial and temporal constraints influence the distribution of fish species and must be considered when making inferences about habitat use and distribution. Dams significantly impact the distribution of fish by preventing migrations between reaches upstream and downstream of the barrier. This can lead to clear patterns in the distribution of fishes where, once historically abundant throughout an entire river, a given species is notably absent upstream or downstream of a barrier. This is likely due to blocked migration to key habitats that meet life history requirements, resulting in extirpation due to mortality or emigration to other reaches that support the diversity of required habitats. Beyond physically preventing movement of fish themselves, dams can also disrupt the connectivity of flow and associated sediment and nutrient transport which can have variable impacts on habitat features causing a shift in the fish community. For example, as dams begin to store in flowing water, the local base level is raised in proportion to the height of the dam [1]. This usually results in an increase in depth and width of the river as a reservoir forms, and a decrease in flow velocities leads to sedimentation as transport ability is lost [1]. Deposition of fine sediments may lead to a shift in species composition within the reservoir. Certain species of fish and macroinvertebrates, an important food source, tend to be associated with particular substrates during specific life stages and a shift to fine sediments may displace species with an affinity for coarser substrates [8]. Below the barrier, changes in flow regime and sediment load can lead to massive reductions in flood peak magnitudes and sediment load [1]. Sediment-starved flows lead to degradation downstream of the dam as erosion increases. This may expose courser substrates, increasing channel roughness and possibly causing more turbulent flow which results in greater local variance and extremes in flow velocity. Species will respond differently to such changes; though in general, studies have shown that increased surface texture and roughness tends to promote greater abundance and diversity of organisms [8]. Despite a likely increase in the exposure of coarse substrates, altered flow regimes may affect access to such areas if flows are greatly reduced and if peak flow timing and volume changes greatly. Fish eggs or larvae may desiccate if discharge decreases and substrates are exposed, while unnaturally extreme flow velocities may wash individuals downstream or cause them to be crushed by shifting substrates. Increased water clarity due to decreased sediment load directly downstream of impoundments may also impact fish communities by promoting growth of periphyton and mosses due decreased light attenuation [8]. This could facilitate a shift toward grazer species and promote colonization by a more diverse macroinvertebrate assemblage beneficial to invertivores and omnivores [58]. Lateral connectivity is also an important consideration for the spatial distribution of fish species in rivers $[25,88]$. Floodplains can support a great diversity of habitats, such as backwater swamps, sloughs and marginal pools, which certain fish species interact with to complete life history requirements such as spawning, and can provide access to different, often higher-quality, food resources [5,58]. In large floodplain rivers, organisms are often adapted to floods and changes in flow regime that alter the timing and magnitude of flood peaks can reduce connectivity with important floodplain habitats. When lateral connectivity is lost, whether from altered flow regimes, dikes, etc., the spatial distribution of certain species may change, either forcing them to emigrate to reaches that provide necessary habitat or increasing mortality through decreased fitness and reproductive output. Drought conditions may have implications for the distribution of fish throughout a riverine system. A review by Rolls et al. [89] identified several negative impacts of low flows and droughts on riverine ecosystems. Low flows control: the extent of habitat available; changes to water quality and habitat conditions; and restrict connectivity and diversity of habitat, influencing the distribution, recruitment, and diversity of biota. 
It is possible that reduced flows have some influence on fish distributions necessitating the use of refugia that may or may not reflect typical habitat preferences [90]. If the geomorphological features are delineated after the construction of barriers or other dramatic changes in connectivity we can expect a geospatial model to account for any changes to channel pattern and related habitat features that may result. In contrast, the model may not be able to detect very recent changes to connectivity, whether from damming or low flow drought conditions, which may impact fish distribution before influencing changes in channel pattern characteristics.

Temporal patterns are another important consideration when examining fish distribution within large rivers. Fish often exhibit complex temporal movement and migration patterns, including considerable diel and/or seasonal migrations, which fish are evolutionarily adapted to for various reasons, including spawning, feeding, predator evasion, and climatic conditions [58,91]. Fish telemetry data may only include observations made during winter months therefore any identified associations and distributions are unlikely to be transferable to patterns which occur during ice-free months [92]. For example, Lake Sturgeon have highly spatially and temporally variable migration patterns, and it has been suggested that they require a minimum $250-300 \mathrm{~km}$ barrier-free combined river and lake range to support a self-sustaining population, with distances of 750-1000 km not being unusual [93]. Individuals tagged in the lower South Saskatchewan and Saskatchewan Rivers by the Water Security Agency reflect these suggested values with individuals migrating an average of $209.9 \mathrm{rkms} \pm 244.6 \mathrm{rkms}$ (mean $\pm 1 \mathrm{SD}$ ) in 2011 [94]. These migrations are generally attributed to movements from deep overwintering "holes" [94-96] to spawning habitats characterized by shallow $(0.6-5 \mathrm{~m})$ fast-flowing areas below rapids [97], deeper slow-velocity summering habitat, or more localized foraging areas [29]. Conversely, single observations of individuals from seining and electrofishing surveys performed at randomized sites are associated with greater uncertainty in terms of spatiotemporal patterns in distribution [98]. One cannot infer whether individuals caught at a given site are resident fish staying within a localized area, are temporarily using the area for a specific life history requirement, or are in the process of migrating and are not actively using the area they were captured in. Without mark-recapture, telemetry, or behavioral observation data one can only infer about how individuals may be interacting with a sample site.

Acknowledgments: Funding sources for this work include the University of Saskatchewan's School of Environment and Sustainability, the Government of Manitoba's Fisheries Enhancement Fund (Project\#12-020), the Saskatchewan Water Security Agency and Environment Canada's Science Horizons Youth Internship Program.

Author Contributions: Excerpts from the University of Saskatchewan PhD thesis "Geospatial modelling of Prairie rivers: linking physical indicators of fish habitat to large scale geomorphic patterns in river systems using geomorphic response units (GRU)", which was written by M.K.C. and supervised by K.-E.L., were used throughout this paper. The conceptualization of the research stemmed from K.-E.L. K.-E.L. promoted this special issue and wrote the "Contributions" section.

Conflicts of Interest: The authors declare no conflict of interest.

\section{References}

1. Knighton, D. Fluvial Forms \& Processes: A New Perspective; Hodder Arnold: London, UK, 1998.

2. Wohl, E. Rivers in the Landscape: Science and Management; Wiley-Blackwell: Hoboken, NJ, USA, 2014.

3. Power, M. The predictive validation of ecological and environmental models. Ecol. Model. 1993, 68, 33-50. [CrossRef]

4. Poff, N.L.; Allan, J.D.; Bain, M.B.; Karr, J.R.; Prestegaard, K.L.; Richter, B.D.; Stromberg, J.C. The natural flow regime. BioScience 1997, 47, 769-784. [CrossRef]

5. Junk, W.J.; Bayley, P.B.; Sparks, R.E. The flood pulse concept in river-floodplain systems. In Proceedings of the International Large River Symposium, Honey Harbour, ON, Canada, 14-21 September 1986; Dodge, D.P., Ed.; Canadian Special Publication of Fisheries and Aquatic Sciences 106; Department of Fisheries and Oceans: Ottawa, ON, Canada, 1989; pp. 110-127.

6. Schumm, S.A. River Variability and Complexity; Cambridge University Press: New York, NY, USA, 2005. 
7. Katopodis, C. Case studies of instream flow modelling for fish habitat in Canadian Prairie Rivers. Can. Water Resour. J. 2003, 28, 199-216. [CrossRef]

8. Allan, J.D.; Castillo, M.M. Stream Ecology: Structure and Function of Running Waters; Springer: Dordrecht, The Netherlands, 2007.

9. Kochel, R.C. Geomorphic impact of large floods: Review and new perspectives on magnitude and frequency. In Flood Geomorphology; Baker, V.R., Kochel, R.C., Patton, P.C., Eds.; Wiley: New York, NY, USA, 1988; pp. 169-187.

10. Walters, D.M.; Leigh, D.S.; Freeman, M.C.; Freeman, B.J.; Pringle, C.M. Geomorphology and fish assemblages in a Piedmont river basin, USA. Freshw. Biol. 2003, 48, 1950-1970. [CrossRef]

11. D'Ambrosio, J.L.; Williams, L.R.; Witter, J.D.; Ward, A. Effects of geomorphology, habitat, and spatial location on fish assemblages in a watershed in Ohio, USA. Environ. Monit. Assess. 2009, 148, 325-341. [CrossRef] [PubMed]

12. Thorp, J.H.; Thoms, M.C.; Delong, M.D. The riverine ecosystem synthesis: Biocomplexity in river networks across space and time. River Res. Appl. 2006, 22, 123-147. [CrossRef]

13. Bizzi, S.; Lerner, D.N. Characterizing physical habitats in rivers using map-derived drivers of fluvial geomorphic processes. Geomorphology 2012, 169-170, 64-73. [CrossRef]

14. Duncan, W.W.; Goodloe, R.B.; Meyer, J.L.; Prowell, E.S. Does channel incision affect in-stream habitat? Examining the effects of multiple geomorphic variables on fish habitat. Restor. Ecol. 2011, 19, 64-73. [CrossRef]

15. James, A.B.W.; Henderson, I.M. Comparison of coarse particulate organic matter retention in meandering and straightened sections of a third-order New Zealand stream. River Res. Appl. 2005, 21, 641-650. [CrossRef]

16. Hoover, T.M.; Richardson, J.S.; Yonemitsu, N. Flow-substrate interactions create and mediate leaf litter resource patches in streams. Freshw. Biol. 2006, 51, 435-447. [CrossRef]

17. Thomson, J.R.; Taylor, M.P.; Fryirs, K.A.; Brierley, G.J. A geomorphological framework for river characterization and habitat assessment. Aquat. Conserv. Mar. Freshw. Ecosyst. 2001, 11, 373-389. [CrossRef]

18. Keithan, E.D.; Lowe, R.L. Primary productivity and spatial structure of phytolitic growth in streams in the Great Smoky Mountains National Park, Tennessee. Hydrobiologia 1985, 123, 59-67. [CrossRef]

19. Pridmore, R.D.; Roper, D.S. Comparison of the macroinvertebrate faunas of runs and riffles in three New Zealand Streams. N. Z. J. Mar. Freshw. Res. 1985, 19, 283-291. [CrossRef]

20. McCulloch, D.L. Benthic macroinvertebrate distributions in the riffle-pool communities of two east Texas streams. Hydrobiologia 1986, 135, 61-70. [CrossRef]

21. Hose, G.C.; Jones, P.; Lim, R.P. Hyporheic macroinvertebrates in riffle and pool areas of temporary streams in south eastern Australia. Hydrobiologia 2005, 532, 81-90.

22. Braaten, P.J.; Berry, C.R. Fish associations with four habitat types in a South Dakota prairie stream. J. Freshw. Ecol. 1997, 12, 477-489. [CrossRef]

23. Chessman, B.C.; Fryirs, K.A.; Brierley, G.J. Linking geomorphic character, behaviour and condition to fluvial biodiversity: Implications for river management. Aquat. Conserv. Mar. Freshw. Ecosyst. 2006, 16, 267-288. [CrossRef]

24. Sullivan, S.M.P.; Watzin, M.C.; Hession, W.C. Influence of stream geomorphic condition on fish communities in Vermont, U.S.A. Freshw. Biol. 2006, 51, 1811-1826. [CrossRef]

25. Schlosser, I.J. Stream fish ecology: A landscape perspective. BioScience 1991, 41, 704-712. [CrossRef]

26. Rabeni, C.F.; Minshall, G.W. Factors affecting microdistribution of stream benthic insects. Oikos 1977, 29, 33-43. [CrossRef]

27. Peckarsky, B.L.; Dodson, S.I. An experimental analysis of biological factors contributing to stream community structure. Ecology 1980, 61, 1283-1290. [CrossRef]

28. Stewart, K.W.; Watkinson, D.A. The Freshwater Fishes of Manitoba; University of Manitoba Press: Winnipeg, MB, Canada, 2004.

29. COSEWIC. COSEWIC Assessment and Update Status Report on the Lake Sturgeon Acipenser Fulvescens in Canada; Committee on the Status of Endangered Wildlife in Canada: Ottawa, ON, Canada, 2006; Volume xi, 107p.

30. Pfeiffer, R.A. Studies on the life history of the Rosyface Shiner, Notropis rubellus. Copeia 1955, 1955, 95-104. [CrossRef] 
31. Watkinson, D.A.; Sawatzky, C.D. Information in support of a recovery potential assessment of Carmine Shiner (Notropis percobromus). Canadian Science Advisory Secretariat (CSAS); Department of Fisheries and Oceans: Ottawa, ON, Canada, 2013; iv, 16p. Available online: http:/ / waves-vagues.dfo-mpo.gc.ca/Library/ 348715.pdf (accessed on 7 March 2018).

32. Zamor, R.M.; Grossman, G.D. Turbidity affects foraging success of drift-feeding Rosyside Dace. Trans. Am. Fish. Soc. 2007, 136, 167-176. [CrossRef]

33. Chiotti, J.A.; Holtgren, J.M.; Auer, N.A.; Ogren, S.A. Lake sturgeon spawning habitat in the Big Manistee River, Michigan. N. Am. J. Fish. Manag. 2008, 28, 1009-1019. [CrossRef]

34. Baldwin, M.E. Habitat Use, Distribution, Life History, and Interspecific Associations of Notropis photogenis (Silver Shiner; Osteichthyes: Cyprinidae) in Canada, with Comparisons with Notropis rubellus (Rosyface Shiner). Master's Thesis, Department of Biology, Carleton University, Ottawa, ON, Canada, 1983.

35. Kempinger, J.J. Spawning and early life history of the lake sturgeon in the Lake Winnebago system, Wisconsin. Am. Fish. Soc. Symp. 1988, 5, 110-122.

36. Scott, W.B.; Crossman, E.J. Freshwater Fishes of Canada Bulletin 184; Fisheries Research Board of Canada: Ottawa, ON, Canada, 1973.

37. Baxter, C.V.; Hauer, F.R. Geomorphology, hyporheic exchange, and selection of spawning habitat by Bull Trout (Salvelinus confluentus). Can. J. Fish. Aquat. Sci. 2000, 57, 1470-1481. [CrossRef]

38. Fausch, K.D.; Torgersen, C.E.; Baxter, C.V.; Li, H.W. Landscapes to riverscapes: Bridging the gap between research and conservation of stream fishes. BioScience 2002, 52, 483-498. [CrossRef]

39. Brewer, S.K.; Papoulias, D.M.; Rabeni, C.F. Spawning habitat associations and selection by fishes in a flow-regulated Prairie river. Trans. Am. Fish. Soc. 2006, 135, 763-778. [CrossRef]

40. Beebe, J.T. Fluid speed variability and the importance to managing fish habitat in rivers. Regul. Rivers Res. Manag. 1996, 12, 63-79. [CrossRef]

41. Rhoads, B.L.; Schwartz, J.S.; Porter, S. Stream geomorphology, bank vegetation, and three-dimensional habitat hydraulics for fish in Midwestern agricultural streams. Water Resour. Res. 2003, 39, 1218. [CrossRef]

42. Yu, B.; Wolman, M.G. Some dynamic aspects of river geometry. Water Resour. Res. 1987, 23, 501-509. [CrossRef]

43. Osterkamp, W.R.; Hedman, E.R. Perennial Streamflow Characteristics Related to Channel Geometry and Sediment in Missouri River Basin; U.S. Geological Professional Paper; USGS: Reston, VA, USA, 1982; Volume 1242, 37p.

44. Dauwalter, D.C.; Splinter, D.K.; Fisher, W.L.; Marston, R.A. Biogeography, ecoregions, and geomorphology affect fish species composition in streams of eastern Oklahoma, USA. Environ. Biol. Fishes 2007, 82, 237-249. [CrossRef]

45. Frothingham, K.M.; Rhoads, B.L.; Herricks, E.E. A multiscale conceptual framework for integrated ecogeomorphological research to support stream naturalization in the agricultural Midwest. Environ. Manag. 2002, 29, 16-33. [CrossRef]

46. Mcllroy, S.K.; Montagne, C.; Jones, C.A.; McGlynn, B.L. Identifying linkages between land use, geomorphology, and aquatic habitat in a mixed-use watershed. Environ. Manag. 2008, 42, 867-876. [CrossRef] [PubMed]

47. Nakamura, F.; Swanson, F.J. Distribution of coarse woody debris in a mountain stream, western Cascade Range, Oregon. Can. J. For. Res. 1994, 24, 2395-2403. [CrossRef]

48. Montgomery, K. Sinuosity and fractal dimension of meandering rivers. Area 1996, 28, 491-500.

49. Nikora, V.I. Fractal structures of river plan forms. Water Resour. Res. 1991, 27, 1327-1333. [CrossRef]

50. Snow, R.S. Fractal sinuosity of stream channels. Pure Appl. Geophys. 1989, 131, 99-109. [CrossRef]

51. Shen, X.H.; Zou, L.J.; Zhang, G.F.; Su, N.; Wu, W.Y.; Yang, S.F. Fractal characteristics of the main channel of Yellow River and its relation to regional tectonic evolution. Geomorphology 2011, 127, 64-70. [CrossRef]

52. Beauvais, A.; Dubois, J.; Badri, A. Fractal analysis applied to river planforms: Method of Richardson. Comptes Rendus De L Acad. Sci. Ser. II 1994, 318, 219-225.

53. Hynes, H.B. The Ecology of Running Waters; University of Toronto Press: Toronto, ON, Canada, 1970.

54. Vannote, R.L.; Minshall, G.W.; Cummins, K.W.; Sedell, J.R.; Cushing, C.E. The River Continuum Concept. Can. J. Fish. Aquat. Sci. 1980, 37, 130-137. [CrossRef]

55. Ward, J.V. The four-dimensional nature of lotic ecosystems. J. N. Am. Benthol. Soc. 1989, 8, 2-9. [CrossRef]

56. Thorp, J.H.; Delong, M.D. The riverine productivity model: An heuristic view of carbon sources and organic processing in large river ecosystems. Oikos 1994, 70, 305-308. [CrossRef] 
57. Humphries, P.; Keckeis, H.; Finlayson, B. The river wave concept: Integrating river ecosystem models. BioScience 2014, 64, 870-882. [CrossRef]

58. Tyus, H.M. Ecology and Conservation of Fishes; CRC Press, Taylor \& Francis Group: Boca Raton, FL, USA, 2012.

59. Thorp, J.H.; Thoms, M.C.; Delong, M.D. The Riverine Ecosystem Synthesis: Toward Conceptual Cohesiveness in River Science; Elsevier: Boston, MA, USA, 2008.

60. Becker, A.; Braun, P. Disaggregation, aggregation and spatial scaling in hydrological. J. Hydrol. 1999, 217, 239-252. [CrossRef]

61. Cammeraat, L.H. A review of two strongly contrasting geomorphological systems within the context of scale. Earth Surf. Process. Landf. 2002, 27, 1201-1222. [CrossRef]

62. Flügel, W.A. Combining GIS with regional hydrological modelling using hydrological response units (HRUs): An application from Germany. Math. Comput. Simul. 1997, 43, 297-304. [CrossRef]

63. Güntner, A.; Bronstert, A. Representation of landscape variability and lateral redistribution processes for large-scale hydrological modelling in semi-arid areas. J. Hydrol. 2004, 297, 136-161. [CrossRef]

64. Sidorchuk, A.; Marker, M.; Moretti, S.; Rodolfi, G. Gully erosion modelling and landscape response in the Mbuluzi River catchment of Swaziland. Catena 2003, 50, 507-525. [CrossRef]

65. Devito, K.; Creed, I.; Gan, T.; Mendoza, C.; Petrone, R.; Silins, U.; Smerdon, B. A framework for broad-scale classification of hydrologic response units on the Boreal Plain: Is topography the last thing to consider? Hydrol. Process. 2005, 19, 1705-1714. [CrossRef]

66. Lindenschmidt, K.-E.; Long, J. A GIS approach to define the hydro-geomorphological regime for instream flow requirements using geomorphic response units (GRU). River Syst. 2013, 20, 261-275. [CrossRef]

67. Carbonneau, P.; Fonstad, M.A.; Marcus, W.A.; Dugdale, S.J. Making riverscapes real. Geomorphology 2012, 137, 74-86. [CrossRef]

68. Church, M.; Ferguson, R.I. Morphodynamics: Rivers beyond steady state. Water Resour. Res. 2015, 51, 1883-1897. [CrossRef]

69. Carbonneau, P.E.; Piégay, H. Fluvial Remote Sensing for Science and Management; John Wiley \& Sons, Ltd.: Hoboken, NJ, USA, 2012.

70. Brierley, G.J.; Fryirs, K.A. Geomorphology and River Management: Applications of the River Styles Framework; Blackwell Publishing: Hoboken, NJ, USA, 2008.

71. Fryirs, K.A.; Brierley, G.J. Geomorphic Analysis of River Systems: An Approach to Reading the Landscape; John Wiley \& Sons, Ltd.: Hoboken, NJ, USA, 2013.

72. Bishop, M.P.; James, L.A.; Shroder, J.F.; Walsh, S.J. Geospatial technologies and digital geomorphological mapping: Concepts, issues and research. Geomorphology 2012, 137, 5-26. [CrossRef]

73. Wheaton, J.M.; Fryirs, K.A.; Brierley, G.; Bangen, S.G.; Bouwes, N.; O’Brien, G. Geomorphic mapping and taxonomy of fluvial landforms. Geomorphology 2015, 248, 273-295. [CrossRef]

74. Kondolf, G.M.; Piégay, H. Tools in Fluvial Geomorphology: Problem Statement and Recent Practice; John Wiley \& Sons, Ltd.: Hoboken, NJ, USA, 2016.

75. Hosseini, N.; Chun, K.P.; Lindenschmidt, K.-E. Quantifying Spatial Changes in the Structure of Water Quality Constituents in a Large Prairie River within Two Frameworks of a Water Quality Model. Water 2016, 8, 158. [CrossRef]

76. Meissner, A.C.N.; Carr, M.K.; Phillips, I.D.; Lindenschmidt, K.-E. Using a Geospatial Model to Relate Fluvial Geomorphology to Macroinvertebrate Habitat in a Prairie River-Part 2: Matching Family-Level Indices to Geomorphological Response Units (GRUs). Water 2016, 8, 107. [CrossRef]

77. Meissner, A.G.N.; Carr, M.K.; Phillips, I.D.; Lindenschmidt, K.-E. Using a Geospatial Model to Relate Fluvial Geomorphology to Macroinvertebrate Habitat in a Prairie River-Part 1: Genus-Level Relationships with Geomorphic Typologies. Water 2016, 8, 42. [CrossRef]

78. Doll, B.; Jennings, G.; Spooner, J.; Penrose, D.; Usset, J.; Blackwell, J.; Fernandez, M. Identifying Watershed, Landscape, and Engineering Design Factors that Influence the Biotic Condition of Restored Streams. Water 2016, 8, 151. [CrossRef]

79. Qiu, S.; Liang, X.; Xiao, C.; Huang, H.; Fang, Z.; Lv, F. Numerical Simulation of Groundwater Flow in a River Valley Basin in Jilin Urban Area, China. Water 2015, 7, 5768-5787. [CrossRef]

80. Chang, C.-H.; Harrison, J.F.; Huang, Y.C. Modeling Typhoon-Induced Alterations on River Sediment Transport and Turbidity Based on Dynamic Landslide Inventories: Gaoping River Basin, Taiwan. Water 2015, 7,6910-6930. [CrossRef] 
81. Fuchs, S.; Kaiser, M.; Kiemle, L.; Kittlaus, S.; Rothvoß, S.; Toshovski, S.; Wagner, A.; Wander, R.; Weber, T.; Ziegler, S. Modeling of Regionalized Emissions (MoRE) into Water Bodies: An Open-Source River Basin Management System. Water 2017, 9, 239. [CrossRef]

82. Chowdhury, E.H.; Hassan, Q.K.; Achari, G.; Gupta, A. Use of Bathymetric and LiDAR Data in Generating Digital Elevation Model over the Lower Athabasca River Watershed in Alberta, Canada. Water 2017, 9, 19. [CrossRef]

83. Ward, J.V.; Stanford, J.A. The serial discontinuity concept of lotic ecosystems. In Dynamics of Lotic Ecosystems; Fontaine, T.D., III, Bartell, S.M., Eds.; Ann Arbor Science Publisher: Ann Arbor, MI, USA, 1983; pp. $43-68$.

84. Kwak, T.J.; Peterson, J.T. Community Indices, Parameters, and Comparisons. In Analysis and Interpretation of Freshwater Fisheries Data; Guy, C.S., Brown, M.B., Eds.; American Fisheries Society: Bethesda, MD, USA, 2007; pp. 677-763.

85. Hayes, D.B.; Ferreri, C.P.; Taylor, W.W. Active fish capture methods. In Fisheries Techniques, 2nd ed.; Murphy, B.R., Willis, D.W., Eds.; American Fisheries Society: Bethesda, MD, USA, 1996; pp. 193-220.

86. Portt, C.B.; Coker, G.A.; Ming, D.L.; Randall, R.G. A Review of Fish Sampling Methods Commonly Used in Canadian Freshwater Habitats; Canadian Technical Report of Fisheries and Aquatic Sciences, Issue 2604; Department of Fisheries and Oceans: Ottawa, ON, Canada, 2006; 51p. Available online: http:/ / publications. gc.ca/collections/collection_2012/mpo-dfo/Fs97-6-2604-eng.pdf (accessed on 7 March 2018).

87. Bayley, P.B.; Dowling, D.C. Gear Efficiency Calibrations for Stream and River Sampling; Illinois Natural History Survey, Aquatic Ecology Technical Report 90/08; INHS Center for Aquatic Ecology: Champaign, IL, USA, 1990.

88. Diana, J.S. Biology and Ecology of Fishes, 2nd ed.; Biological Science Press, Cooper Pub. Group: Traverse City, MI, USA, 2004.

89. Rolls, R.J.; Leigh, C.; Sheldon, F. Mechanistic effects of low-flow hydrology on riverine ecosystems: Ecological principles and consequences of alteration. Freshw. Sci. 2012, 31, 1163-1186. [CrossRef]

90. Carr, M.K.; Watkinson, D.A.; Svendsen, J.C.; Enders, E.C.; Long, J.; Lindenschmidt, K.-E. Geospatial modelling of the Birch River: Spawning distribution of Carmine Shiner (Notropis percobromus) in Geomorphic Response Units (GRU). Int. Rev. Hydrobiol. 2015, 100, 1-12. [CrossRef]

91. Nunn, A.D.; Copp, G.H.; Vilizzi, L.; Carter, M.G. Seasonal and diel patterns in the migrations of fishes between a river and a floodplain tributary. Ecol. Freshw. Fish 2010, 19, 153-162. [CrossRef]

92. Carr, M.; Lacho, C.; Pollock, M.; Watkinson, D.; Lindenschmidt, K.-E. Development of geomorphic typologies for identifying Lake Sturgeon (Acipenser fulvescens) habitat in the Saskatchewan River System. River Syst. 2015, 21, 215-227. [CrossRef]

93. Auer, N.A. Importance of habitat and migration to sturgeons with emphasis on lake sturgeon. Can. J. Fish. Aquat. Sci. 1996, 53, 152-160. [CrossRef]

94. WSA. Saskatchewan River Sturgeon Report 2012; Water Security Agency: Moose Jaw, SK, Canada, 2013.

95. SWA. Saskatchewan River Sturgeon Report 2010; Saskatchewan Watershed Authority: Moose Jaw, SK, Canada, 2011.

96. SWA. Saskatchewan River Sturgeon Report 2011; Saskatchewan Watershed Authority: Moose Jaw, SK, Canada, 2012.

97. Wallace, R.G. Species Recovery Plan for Lake Sturgeon in the Lower Saskatchewan River (Cumberland Lake Area); Fisheries Technical Report 91-3; Fisheries Branch Saskatchewan Parks and Renewable Resources: Regina, SK, Canada, 1991; 51p.

98. Carr, M.K.; Watkinson, D.A.; Lindenschmidt, K.-E. Identifying Links between Geomorphic Response Units (GRU) and Fish Species in the Assiniboine River, Manitoba. Ecohydrology 2016, 9, 1154-1165. [CrossRef]

(C) 2018 by the authors. Licensee MDPI, Basel, Switzerland. This article is an open access article distributed under the terms and conditions of the Creative Commons Attribution (CC BY) license (http://creativecommons.org/licenses/by/4.0/). 